\title{
Using the Set Theory Module in Think Pair Share Learning, Is It Effective?
}

\author{
Istiqomah $^{1}$, Denik Agustito ${ }^{2}$ \\ ${ }^{1}$ Department of Mathematics Education, Universitas Sarjanawiyata Tamansiswa \\ Jl. Batikan UH III/1043 Umbulharjo \\ Yogyakarta, Indonesia \\ E-mail: istiqomah@ustjogja.ca.id \\ ${ }^{2}$ Department of Mathematics Education, Universitas Sarjanawiyata Tamansiswa \\ Jl. Batikan UH III/1043 Umbulharjo \\ Yogyakarta, Indonesia \\ E-mail: rafaelagustito@gmail.com
}

\begin{abstract}
This study aims to determine the effectiveness of the use of set theory modules in Think Pair Share learning on independence and student learning outcomes. This research is a quasi-experimental research with Posttest-Only Control Design. The subjects in this study were students of the mathematics education program class 2019 class A as an experimental class. Data collection techniques used were tests, questionnaires, and documentation techniques. Data analysis uses descriptive statistics to reveal trends in initial abilities, learning independence, and learning outcomes. Data analysis using the t-test to test hypotheses with previously carried out the balance test, normality test, and homogeneity test. The results of this study indicate that the use of the Set Theory module in Think Pair Share learning is no more effective than without the use of the Set Theory module in Think Pair Share learning on student independence and learning outcomes
\end{abstract}

Keywords: effectiveness, module, Think Pair Share, independence, learning outcome.

\section{Introduction}

The set is the basic concept of all branches of mathematics. The set Theory of Compulsory Theory must be taken by first semester students in the mathematics education study program at the Faculty of Teacher Training and Science at Sarjanawiyata Tamansiswa University (FKIP UST). Mathematics education study program students are teacher candidates who are targeted to become secondary and high school teachers. As a prospective teacher, students of mathematics education study programs are expected to understand the material of the set well [1], [2], because the set is one of the materials that will be taught when they become teachers. If the teacher has a good background in knowledge then when he teaches he will master what he teaches [3], [4].
Based on observations made in the Mathematics Education Study Program FKIP UST, it shows that the learning process in the set Theory The subject is not optimal. The absence of variations in the application of learning models in lectures so that students look bored, less interested, and passive. In addition, students are not independent in learning, do not have the initiative to study the material before lectures take place. This lack of interest and independence has resulted in low student learning outcomes, even though the set material they have already obtained while attending secondary school. As a prospective mathematics teacher, in addition to having to master the concepts students must also have independence in learning. Students are required to be active and creative, able to develop their ideas to construct their thoughts [5], [6]. Efforts can be made by educators to improve the learning independence of 
students one of which is to provide good teaching materials [7]-[9]. Alternative teaching materials that can be used are modules. The role of modules in learning is that it can provide students the flexibility in solving math problems [10], [11]. Modules are teaching materials that can help students to learn independently [11]. The use of modules as teaching material in mathematics learning can improve mathematics learning skills, motivation and positive attitudes in learning mathematics [12].

Applying the right learning model will also affect the quality of the learning process. One learning model that can be applied to increase independence and learning outcomes is the Think-Pair-Share (TPS). Think Pair Share learning model is a type of cooperative learning that is designed to influence learners' interaction patterns [13]. Educators can create interactions that encourage curiosity, want to try, be independent, and want to advance students [14]. The TPS learning model gives students the opportunity to think and respond and help one another [15]. Think Pair Share has an explicitly established procedure to give students more time to think, answer, and help each other [13].

The stages in the TPS learning model include: (1) thinking, educators ask questions related to the material to be discussed, then students are asked to think about questions independently for a few moments. In this stage, students are required to be independent in processing information that has been obtained; (2) pairing, students pair up with other students to discuss what has been thought at the thinking stage. Interaction at this stage is expected to be able to share answers with their partners, (3) sharing, students share answers with the whole class about what they have discussed.

Based on the above, it is expected that through the TPS learning model students can improve their independence and learning outcomes. The aim of the researcher is to find out the effectiveness of the use of set theory modules in TPS learning on independence and student learning outcomes.

\section{Method}

This research is a quasi-experimental research design with "Posttest-Only Control Design. This quasiexperimental research involves two classes, namely the experimental class, and the control class. The treatment is given to the experimental class in the form of the use of the Theory Theory module in TPS learning, while in the control class without the use of the Theory Theory module in TPS learning. After the treatment, the impact that appears on the research subjects is examined as a result of the applied learning treatment namely independence and student learning outcomes in mathematics.

The subjects in this study were students of the mathematics education program class 2019 class A as an experimental class totaling 30 students and class B as a control class with 33 students. Data collection techniques using questionnaires, tests, and documentation. Questionnaire techniques to measure learning independence, test techniques to uncover student learning outcomes data in the Theory of Assets in the Relationship chapter, and documentation techniques to obtain initial ability data.

The instruments in this study were modules, questionnaires, and tests. Before the module is used in learning, the module is first validated which includes the following aspects of assessment: aspects of teaching materials, aspects of the material, aspects of an organization, presentation, and writing, and aspects of language and readability [9]. The independence questionnaire includes indicators of confidence, discipline, initiative, responsibility, and motivation. The questionnaire consisted of 30 items of statements, using a Likert scale of 1 to 4 . Learning lattice test grids included 1) stating relations in ordered pairs, 2) determining the domain, range, inverse relations of relations, 3) identifying a relation as equivalent relation or not. Data analysis techniques in this study include descriptive statistical analysis techniques, balance test, normality test, homogeneity test, and hypothesis testing with t-test.

\section{Result and Discussion}

\subsection{Module Validation}

The module that will be used first is validated by the module expert. In this study, the module was validated by 3 module experts. A summary of the validation results from three validators is presented in the following Table 1 .

Table 1. Summary of Module Validation Results

\begin{tabular}{clc}
\hline No & \multicolumn{1}{c}{ Indicator } & Average Score \\
\hline 1. & Aspects of Teaching Materials & 3,5 \\
& Structure & 4,33 \\
2. & $\begin{array}{l}\text { aspects of the material } \\
\text { 3. }\end{array}$ & 4,22 \\
& $\begin{array}{l}\text { pspects of an organization, } \\
\text { 4. }\end{array}$ & 4,22 \\
& aspects of language and readability & 4,07 \\
\hline
\end{tabular}


Table 1 shows that the overall module average is 4.07 or in either category. While the recommendations of the three validators are modules worth using with revisions

\subsection{Data Description}

\section{Initial Ability}

Based on the initial ability data obtained an ideal maximum score of 100 and an ideal minimum score of 0 , so that the obtained ideal average $=50$ and ideal standard deviation $=16.67$.

By observing the ideal mean and ideal standard deviation, the ideal normal curve criteria can be showed in Table 2.

Tabel 2. Criteria for the Ideal Normal Curve

\begin{tabular}{cc}
\hline Interval & Criteria \\
\hline $\bar{X}>75,005$ & Very high \\
$58,335<\bar{X} \leq 75,005$ & High \\
$41,665<\bar{X} \leq 58,335$ & Enough \\
$24,995<\bar{X} \leq 41,665$ & Low \\
$\bar{X} \leq 24,995$ & Very low \\
\hline
\end{tabular}

The initial ability data was taken from the UTS score data for The Odd Semester Semester Academic Year 2019/2020. By using the documentation technique, it was found that the average initial ability of the experimental class was 37.33 and the control class was 40.12 .

The experimental class and the control class have relatively similar initial ability values of 37.53 for the experimental class and 40.12 for the control class. Both are included in the interval $24,995<41,665$ with a low category. This situation indicates that students do not understand the material provided before the relation material that is the material relations between sets, basic operations of the set, and the set of numbers. Although this set of materials is not new to students, they still encounter many difficulties when meeting with the problems of the set.

The material that is considered difficult by students in this initial ability test is the power set/ power set material and the material proving a statement that is stated with the set notation. In powerset material, the difficulties experienced include: 1) students still cannot distinguish between the concepts of powerset and the concept of family set, 2) students are not yet skilled at identifying a set whether a powerset or not, 3 ) determine the number of powerset members. Then in the material of proof, students have not been able to find proof of idea or purpose of the statement that must be proven. Therefore, based on the identification of difficulties experienced by students, the lecturer must find the right solution to minimize errors that occur in solving the problem of set theory. From a psychological point of view, students of the class of 2019 are new students who are still in the stage of adjustment to university mathematics material. Students are still in the process of constructing thinking, so they are used to thinking logically and systematically. So it is quite natural if they encounter a lot of difficulties working on universitylevel mathematical problems. However, students must continue to strive so those mathematical concepts can be understood properly and correctly.

Learning Independence

Based on the learning independence data, an ideal maximum score of 150 and an ideal minimum score of 30 is obtained in order to obtain an ideal average $(\mathrm{MI})=$ 90 and an ideal standard deviation $($ SDI $)=20$. By considering the ideal mean and ideal standard deviation, it can be arranged ideal normal curve criteria is presented in the following Table 3.

Table 3. Criteria for the Ideal Normal Curve

\begin{tabular}{cc}
\hline Interval & Criteria \\
\hline $\bar{X}>120$ & Very high \\
$100<\bar{X} \leq 120$ & high \\
$80<\bar{X} \leq 100$ & Enough \\
$60<\bar{X} \leq 80$ & Low \\
$\bar{X} \leq 60$ & Very low \\
\hline
\end{tabular}

Learning independence data was taken from the independence questionnaire filled out by students and obtained an average score of learning independence of experimental class 120.33 and control class 120.73 .

The experimental class and the control class had relatively similar learning independence scores, namely 120.33 for the experimental class and 120.73 for the control class. Both are included in intervals> 120 included in the high category. This situation illustrates that the independence of students measured from aspects of self-confidence, discipline, initiative, responsibility, and motivation tends to be high. In detail, the learning independence shown in the following matters: students are enthusiastic in participating in 
group discussions, not ashamed when speaking in front of the class, dare to express opinions when the lecturer provides an opportunity, challenged to find out more about the material delivered by the lecturer, have the initiative to form study groups with friends, have the desire to try to practice difficult questions, try to do the task/ problem until it works.

\section{Mathematical Learning Outcome}

Based on the learning outcomes data obtained an ideal maximum value of 100 and an ideal minimum value of 0 in order to obtain the ideal average $(\mathrm{MI})=50$ and the ideal standard deviation $(\mathrm{SDI})=16.67$. By observing the ideal mean and ideal standard deviation, the normal curve criteria use table 2 , because the initial ability data and learning outcome data have the same ideal mean and ideal standard deviation. From the data of students' mathematics learning outcomes (posttest) obtained the average data of learning outcomes of the experimental class was 49.53 and the control class was 48.39 .

The experimental class and the control class had relatively similar learning outcomes of 49.53 for the experimental class and 48.39 for the control class. Both are included in the interval $41,665<58,335$ included in the sufficient category. This situation illustrates that students are already quite familiar with the material of the relation, that is, the student is sufficiently able to declare relations in ordered pairs, determine the domain, range, inverse relations of a relation, and identify a relation as an equivalent relation or not. But when viewed from the average value, the results obtained are not optimal. Most mistakes experienced by students are in determining a relation is an equivalent relationship or not. Most students do not yet understand the concept of reflexive, symmetrical, and transitive relations which are conditions of equivalent relations. Students are still having trouble identifying whether the relation that is defined from an open sentence is a reflexive, symmetrical, and transitive relation. This situation is an evaluation material for lecturers, that there is a need to strengthen the concept of equivalent relations and explain again the kinds of relations.

\subsection{Test Prerequisite Analysis}

\section{Balance Test}

The criteria for testing the balance test is that the population is in a balanced state if the statistical value of the test is not in the critical region, namely $-\mathrm{t}>\mathrm{t}$-table or $\mathrm{t}$-count $<\mathrm{t}$ table. Data analysis obtained $\mathrm{t}$-count $=$ $1.189<$ ttable $=2.001$, it can be concluded that the two groups came from two populations with the same initial ability or two populations in a balanced state.

\section{Normality test}

The Normality test is carried out on the initial ability data, learning independence, and learning outcomes of each data group, namely the experimental group and the control group. The Liliefors test criteria are the sample that comes from populations that are normally distributed if the significance value $(\mathrm{sig})>0.05$. Based on the data processing output with SPSS 23 software, the results are that the initial ability data, learning independence, and learning outcomes of the experimental and control groups meet normality assumptions or come from populations that are normally distributed

\section{Homogeneity test}

The homogeneity test is performed on the initial ability data, learning independence data, and learning outcome data. Homogeneity testing uses SPSS 23 software, namely by comparing the significance value (sig), if the sig value> 0.05 then the data meets the assumption of homogeneity. Based on the data processing output with SPSS 23 software, the results are that the initial ability data, learning independence, and learning outcomes meet the assumptions of homogeneity or come from populations with homogeneous variances.

\section{Test the average difference of learning independence}

Data analysis gives the result that the value of $\operatorname{sig}=$ $0.477>0.5$ which gives meaning that there is no difference in the average independence between students who are given the treatment of the use of modules in TPS learning and without the use of modules in TPS learning.

Based on the results of the hypothesis test, it was found that the value of $\mathrm{sig}=0.477>0.5$, which means that there is no difference in the average independence between the experimental class and the control class. This result is reinforced by descriptive statistical data that show the average score of learning independence is almost the same, namely 120.33 and 120.73 .

This situation shows that students who are treated using modules in TPS learning have the same independence as 
students who are treated without using modules in TPS learning. From these results, it appears that the use of modules does not have an effect or impact on student independence. This is because students have a high awareness of learning whether given a module or not. Students are able to express their opinions, able to study with their friends by creating small groups, always trying to find sources of knowledge both from books in the library and from the internet. For information that even though the control class is not given a module, but they use the book of a set theory they get from sister level. So even though the control class is not given a module, they still use teaching material that is their guide in learning.

In addition, the application of the TPS learning model greatly affects student independence. In the Think stage, students think independently of the given problem. Before students are given problems related to relations material, the lecturer first gives a presentation of the material. After the Think stage, the next stage is pair, students pair up with friends to discuss issues related. Learning independence is very visible in this phase, namely, students are confident in expressing opinions, not ashamed to ask questions, eager to solve the problems given. The class atmosphere became very lively with this paired discussion. This is in line with research conducted by [16] which states that paired discussions can train students to dare to express opinions and actively discuss with their partner partners. The results of research conducted by [14] also revealed the same thing that with TPS learning students become more enthusiastic in participating in learning. The next stage is sharing, students express their opinions on the problem given based on the results of discussions with their partner partners.

\section{Test the average difference in learning outcomes}

Data analysis gives the result that the value of sig = $0.191>0.5$ which gives the meaning that there is no difference in the average learning outcomes between students who are given the treatment of the use of modules in TPS learning and without the use of modules in TPS learning.

Based on the results of the hypothesis test, it was found that the value of $\operatorname{sig}=0.191>0.5$ which means that there is no difference in the average learning outcomes between the experimental class and the control class. These results are reinforced by descriptive statistical data that show almost the same learning outcomes of 49.53 and 48.39 .
This shows that students who are treated using modules with TPS learning have the same learning outcomes as students who are treated without using modules in TPS learning. From these results, it appears that the use of modules does not have an effect or impact on student learning outcomes. Think Pair Share (TPS) learning model has a good impact on learning outcomes if implemented correctly. In accordance with the results of research conducted by [14] that the application of the TPS model can improve student activity and learning outcomes

In this study, researchers have carried out the three stages that form the basis of this model, namely Think, students, think independently, then Pair, students are asked to pair up with friends can be left or right side, and finally is Share, students share or submit the results of discussions in the pair stage. Students convey difficulties to their friends about the problems faced, if they still don't understand, they ask other groups. The process of exchanging opinions has a positive impact on students' ability to solve the given problems. Students become more understanding and can provide answers to problems that are given, and finally, students are able to solve problems, even though the results are still in a sufficient category. Therefore, although the control class is not given a module, but as it has been revealed that students use other teaching materials, namely textbooks and materials from the internet, so that even without the use of modules they do not have an impact on students, because both classes get the same treatment TPS learning models can improve learning outcomes in mathematics.

\section{Conclusion}

The conclusion of the study is: there is no difference in learning independence and learning outcomes between students who are given the treatment of the use of modules in TPS learning and students who are treated without using modules in learning TPS. In other words, the use of modules in TPS learning is no more effective than without the use of modules in TPS learning.

\section{References}

[1] A. R. As'ari, A. Mahmudi, and E. Nuerlaelah, "Our Prospective Mathematic Teachers Are Not Critical Thinkers Yet," J. Math. Educ., vol. 8, no. 2, pp. 145156, 2017.

[2] F. Depaepe et al., "Teachers' content and pedagogical content knowledge on rational numbers: 
A comparison of prospective elementary and lower secondary school teachers," Teach. Teach. Educ., vol. 47, no. June, pp. 82-92, 2015.

[3] B. Giacomone, P. Beltrán-Pellicer, and J. D. Godino, "Cognitive analysis on prospective mathematics teachers' reasoning using area and tree diagrams," Int. J. Innov. Sci. Math. Educ., vol. 27, no. 2, pp. 1832, 2019.

[4] S. A. Widodo, M. Irfan, H. Fitriyani, K. S. Perbowo, and T. Trisniawati, "Visual Media in Team Accelerated Instruction to Improve Mathematical Problem-Solving Skill," in ICSTI 2018, October 1920, Yogyakarta, Indonesia, 2019, pp. 1-10.

[5] R. Wegerif, L. Li, and J. C. Kaufman, The routledge international handbook of research on teaching thinking. 2015.

[6] M. Irfan, T. Nusantara, Subanji, and Sisworo, "Students know the concept but are wrong in solving the proportional problem: How did it happen?," Int. J. Sci. Math. Technol. Learn., vol. 27, no. 1, 2019.

[7] S. Livy and S. Herbert, "Second-year pre-service teachers' responses to proportional reasoning test items," Aust. J. Teach. Educ., vol. 38, no. 11, pp. 17 32, 2013.

[8] J. A. Van de Walle, K. S. Karp, and J. M. BayWilliams, Elementary and Middle School Mathematics: Teaching Developmentally. 2010.

[9] S. Sujatmika, M. Irfan, T. Ernawati, A. Wijayanti, and S. A. Widodo, "Designing E-Worksheet Based On Problem-Based Learning To Improve Critical Thinking," in ICSTI 2018, October 19-20, Yogyakarta, Indonesia, 2019, pp. 1-8.

[10] N. Angraini and R. Masykur, "Modul Matematika Berdasarkan Model Pembelajaran Problem Based Learning Materi Pokok Trigonometri," Desimal J. Mat., vol. 1, no. 2, pp. 217-228, 2018.

[11] S. Prisha Bahri, Y. Sukestiyarno, K. Pascasarjana Unnes, and J. Kelud, "Unnes Journal of Mathematics Education Research Problem Solving Ability on Independent Learning and Problem Based Learning with Based Modules Ethnomatematics Nuance," Ujmer, vol. 7, no. 2, pp. 218-224, 2018.

[12] B. Lawlor, S. McLoone, and A. Meehan, "The Implementation and Evaluation of a Problem Based Learning Pilot Module in a First Year Electronic Engineering Programme.," 5th Int. Symp. Eng. Educ., vol. 4, no. 1, pp. 71-80, 2014.

[13] K. M. Curtis, "Improving student attitudes: A study of a mathematics curriculum innovation," ProQuest Diss. Theses, p. 210, 2006.

[14] A. Izsak, E. Tillema, and Z. Tunc-Pekkan, "Teaching and learning fraction addition on number lines," $J$. Res. Math. Educ., vol. 39, no. 1, pp. 33-62, 2008.

[15] V. T. A. Sari and P. Nurfauziah, "Development of
Trigonometry Teaching Materials with Knisley Mathematical Models," in ICSTI 2018, October 1920, Yogyakarta, Indonesia, 2019, pp. 1-8.

[16] R. Otty and L. Milton, "Promoting soft skills with the HOT ( Higher Order Thinking ) sheet assignment," vol. 22 , pp. 1-20. 